\title{
TIPOLOGI PENGEMBANGAN RUMAH SUBSIDI OLEH PENGHUNI DI KOTA KUPANG NUSA TENGGARA TIMUR (NTT)
}

\author{
I Gusti Ngurah Wiras Hardy ${ }^{1}$, Rifat Y. Y. Maromon², Debri Andries Amabi ${ }^{3}$ \\ ${ }^{1,2,3}$ Program Studi Arsitektur, Fakultas Sains dan Teknik, Universitas Nusa Cendana, Kupang NTT
}

Penulis korespondensi: I Gusti Ngurah Wiras Hardy, ihardy@staf.undana.ac.id

Naskah diajukan pada: 05 November 2020

Naskah revisi akhir diterima pada: 02 Maret 2021

\begin{abstract}
Abstrak
Rumah subsidi merupakan program pemerintah yang ditujukan kepada Masyarakat Berpenghasilan Rendah (MBR) untuk mendorong kepemilikan rumah dengan skema pembiayaan secara kredit yang disubsidi pemerintah. Program ini telah dimulai sejak tahun 2010 secara nasional termasuk di Kota Kupang NTT, yang bertujuan untuk mengatasi backlog perumahan dan mendorong tercapainya target satu juta rumah yang dicanangkan pemerintah. Fasilitas yang terdapat pada rumah subsidi di Kota Kupang, umumnya sudah layak dan memadai. Dalam perkembangannya, penghuni rumah subsidi di Kota Kupang mengembangkan rumahnya di lahan yang masih tersisa. Hal ini memunculkan fenomena pengembangan rumah subsidi oleh penghuni. Fenomena ini menarik untuk diteliti, untuk memperoleh pemahaman mengenai keragaman tipe pengembangan rumah subsidi dan pelbagai pertimbangan yang melatarbelakanginya. Penelitian ini menggunakan pendekatan metode penelitian kualitatif dengan paradigma rasionalistik untuk mengkaji tipologi pengembangan rumah subsidi berdasarkan teori dan kondisi empiris di lapangan. Berdasarkan hasil penelitian, dapat dirumuskan tiga tipe pengembangan rumah subsidi yang dirumuskan menurut kategorisasi dan kombinasi aspek pembentuk elemen pengembangan rumah pada ruang dalam, ruang luar dan fasad rumah. Keragaman tipe pengembangan rumah tersebut dilatarbelakangi oleh pertimbangan tertentu dengan tujuan untuk mengoptimalkan fungsi rumah dalam memenuhi kebutuhan penghuni.
\end{abstract}

Kata-kata Kunci: Tipologi, Pengembangan, Rumah Subsidi, Kota Kupang, NTT

\section{TYPOLOGY OF SUBSIDIZED HOUSE DEVELOPMENT BY THE RESIDENT IN KUPANG CITY NUSA TENGGARA TIMUR (NTT)}

\begin{abstract}
The subsidized house is a government programming aimed at the Low-Income Communities $(M B R)$ to encourage homeownership with a subsidized credit financing scheme by the government. Since 2010 the program has been started nationally, including in Kupang City-NTT, to overcome the backlog of housing and encourage the achievement of the one million house target set by the government. The facilities in Kupang City subsidized houses generally are proper and adequate. During its development, the residents of Kupang City subsidized houses are developed their houses on the remaining land, and it's caused the phenomenon of subsidized housing development by its residents. This phenomenon is interesting to research and for understanding various types of developments subsidized houses and the various considerations behind it. This research used the
\end{abstract}


qualitative research method approach with a rationalistic paradigm to examine the typology of the development of subsidized houses based on the theory and empirical conditions in the locations. Based on the research results, there are three types of developments of the subsidized houses that can be formulated according to the categorization and combination of forming aspects of home development elements in the interior, outer space, and house facades. The diverse types of house development are motivated by specific considerations to optimize the function of the house in meeting the needs of residents.

Keywords: Typology, Development, Subsidized Houses, Kupang City, NTT

\section{Pendahuluan}

Rumah subsidi merupakan rumah yang pembiayaannya disubsidi oleh pemerintah, diantaranya melalui program KPR-FLPP (Kredit Pemilikan Rumah-Fasilitas Likuiditas Pembiayaan Perumahan) atau skema subsidi dana bergulir. Program ini telah dimulai secara nasional sejak tahun 2010, yang bertujuan untuk mengatasi backlog perumahan dan membantu masyarakat berpenghasilan rendah (MBR) untuk memiliki rumah layak huni dan terjangkau (Ayu \& Elena, 2019). Nusa Tenggara Timur merupakan salah satu provinsi di Indonesia yang telah melaksanakan program rumah subsidi sejak tahun 2010. Hal ini ditandai dengan dibangunnya beberapa perumahan subsidi oleh beberapa developer, yang bekerja sama dengan bank pemerintah untuk menyalurkan KPR-FLPP. Menurut Ketua DPD REI NTT, Bobby Pitoby (dalam Rachmawati, 2019), rumah subsidi di NTT pada tahun 2019 telah terserap sebanyak 85-90 persen. Oleh karena itu, banyak masyarakat NTT yang telah memanfaatkan program ini untuk memiliki rumah pribadi.

Rumah subsidi umumnya memiliki standar fasilitas yang telah ditetapkan oleh pemerintah, namun developer di NTT tetap menyediakan luas tanah yang dapat dikembangkan oleh penghuni di kemudian hari. Hal ini sesuai dengan prinsip rumah tumbuh, yang fasilitasnya dapat ditambah sesuai dengan kebutuhan dan kemampuan penghuninya. Berdasarkan hasil pengamatan di beberapa perumahan subsidi, para penghuni rumah telah melakukan beberapa pengembangan. Diantaranya modifikasi ruang dan penambahan ruang di lahan yang masih tersisa. Hal ini menimbulkan fenomena pengembangan rumah subsidi oleh penghuni dengan pelbagai ragam. Fenomena pengembangan rumah subsidi ini menarik untuk dikaji, terutama mengenai tipologi pengembangan rumah subsidi oleh penghuni.

Menurut Moneo (1978), tipologi dalam arsitektur merupakan studi yang mendeskripsikan suatu kelompok objek amatan berdasarkan kesamaan karakter bentuk dasarnya. Pada awalnya, studi ini menekankan pada manifestasi mode-mode dari tempat tinggal (Schulz, 1985). Oleh karena itu, dengan tipologi dapat diperoleh gambaran tipe-tipe yang lebih sederhana dari keragaman rumah tinggal berdasarkan aspek tertentu. Menurut Sulistijowati (1991), aspek tersebut diantaranya aspek fungsi, geometrik, dan langgam. Tipe dapat mengimplikasikan ide dari perubahan dan transformasi. Selain itu, munculnya tipe-tipe tersebut dapat pula menunjukan perubahan sosiokultural dan teknologi (Moneo, 1978). Oleh karena itu, studi tipologi ini dapat dijadikan sebagai pedoman untuk mengkaji fenomena keragaman pengembangan rumah subsidi oleh penghuni di Kota Kupang NTT menurut aspek tertentu. Dengan demikan, dapat diperoleh deskripsi mengenai tipe rumah subsidi pasca dikembangkan oleh penghuni, dan pemahaman mengenai gagasan atau pertimbangan penghuni dalam mengembangkan rumahnya.

Hingga saat ini, penelitian-penelitian mengenai tipologi dan perumahan telah beberapa kali dilakukan. Penelitian mengenai tipologi dalam arsitektur, diantaranya dilakukan oleh: Wicaksono, dkk (2008) mengenai tipologi rumah tinggal pada perumahan karyawan pabrik gula; Faisal, dkk (2012) mengenai tipologi ventilasi bangunan vernakular; Mithen (2015) mengenai tipologi arsitektur tradisional Mamasa; Asmarani, dkk (2016) mengenai tipologi elemen arsitektur Rumah Bangsal; 
Prabowo dan Roychansyah (2017) mengenai tipologi rumah tinggal dengan harga Rp. 100-200 juta; Rahman, dkk (2018) mengenai tipologi bangunan pada kawasan Simarjarunjung; Ramli (2018) mengenai tipologi fasad rumah tradisional Kampung Ciptagelar; dan Santoso, dkk (2019) mengenai tipologi Rumah-Ladang. Sementara itu, penelitian mengenai permukiman, perumahan, dan rumah subsidi, diantaranya dilakukan oleh: Siswanti (2013); Mangeswuri (2016); Yuliastuti dan Sukmawati (2016); Hartanu dan Firdausy (2018); Musyaqqat (2018); Adlina (2019); Huwaida dan Harsritanto (2019); Kamim, dkk (2019); Supeno dan Ansori (2019); Widodo dan Sunarti (2019); Hardy, dkk (2020). Secara umum, penelitian tersebut belum ada yang mengkaji mengenai tipologi pengembangan rumah subsidi dan pertimbangan yang mendasarinya. Oleh karena itu, penelitian ini memiliki kekhasan gap teoritik dan urgensi yang berbeda dengan penelitian sebelumnya, yaitu mengkaji tipologi terhadap fenomena pengembangan rumah subsidi oleh penghuninya di Kota Kupang, NTT. Hasil dari penelitian ini dapat pula memverifikasi kembali konsep tipologi dan tipe dalam arsitektur (Moneo, 1978) pada objek dan kurun waktu yang berbeda, yaitu tipologi pengembangan rumah subsidi pada masa sekarang.

Dengan demikian, penelitian ini dapat melengkapi penelitian-penelitian sebelumnya yang mengkaji mengenai fenomena permukiman, perumahan dan rumah subsidi di Indonesia. Selain itu, hasil penelitian ini diharapkan pula dapat menjadi sumber referensi bagi masyarakat, terutama bagi masyarakat yang ingin mengembangkan rumahnya secara optimal. Sementara itu, bagi developer dan pemerintah dapat menjadi bahan masukan dalam hal penyusunan kebijakan dan penyediaan jenis, tipe, dan fasilitas rumah subsidi yang lebih optimal bagi masyarakat di masa mendatang.

\section{Metode}

Berdasarkan latar belakang penelitian, maka metode penelitian yang digunakan untuk penelitian ini adalah metode penelitian kualitatif dengan paradigma rasionalistik. Metode penelitian kualitatif dengan paradigma rasionalistik sesuai digunakan dalam penelitian ini karena bertujuan untuk mengkaji tipologi pengembangan rumah subsidi oleh penghuni yang berpedoman pada grand theory dan pengamatan empiris di lapangan. Penelitian ini berpedoman pada teori tipologi (Moneo, 1978), elemen-elemen rumah dan aspek-aspek pembentuk elemen rumah yang diidentifikasi dari proses pengamatan awal (grandtour) yang didialogkan dengan aspek tipologi menurut Sulistijowati (1991), untuk mengidentifikasi tipe-tipe pengembangan rumah subsidi oleh penghuni di Kota Kupang, NTT.

Penelitian ini menggunakan empat teknik pengumpulan data, yaitu observasi lapangan, wawancara terstruktur, dokumentasi, dan studi dokumen. Dalam proses observasi lapangan, elemenelemen rumah menjadi unit-unit amatan, sedangkan aspek-aspek pembentuk elemen rumah menjadi sub-sub unit amatan. Unit-unit amatan dan sub-sub unit amatan tersebut, dapat dijelaskan sebagai berikut:

1. Unit amatan yaitu elemen-elemen rumah yang diidentifikasi dari proses pengamatan awal (grand tour), terdiri dari: (a) bagian ruang dalam; (b) bagian ruang luar; dan (c) fasad rumah.

2. Sub-sub unit amatan yaitu aspek-aspek pembentuk elemen rumah yang diidentifikasi dari proses pengamatan awal (grand tour) yang didialogkan dengan aspek tipologi menurut Sulistijowati (1991), terdiri dari: (a) tatanan; (b) material; (c) warna; dan (d) ragam hias (ornamen/dekorasi).

Analisis data yang digunakan menggunakan pendekatan deduktif-kualitatif dengan berpedoman pada proses analisis tipologi menurut Moneo (1978). Analisis data diawali dengan melakukan penyusunan atau pengklasifikasian data rumah, dilanjutkan dengan tahap konfirmasi dan pemberian kode (coding) sesuai dengan unit-unit amatan dan sub-sub unit amatan. Proses selanjutnya mengkategorisasikan data menurut hubungan-hubungan antar unit-unit amatan dan subsub unit amatan, dilanjutkan proses reduksi dan perumusan tipe-tipe pengembangan rumah subsidi. Proses terakhir dari kegiatan analisis data adalah proses penyimpulan hasil temuan. 
Lokasi penelitian terletak di Kota Kupang, Nusa Tenggara Timur (NTT) karena merupakan pusat pelbagai perkembangan, salah satunya sektor perumahan. Sejak adanya program rumah subsidi, pembangunan perumahan dan permintaan rumah subsidi relatif bertambah. Perumahan dan rumah yang dijadikan objek penelitian dipilih dengan teknik purposive sampling, dengan kriteria sebagai berikut:

1. Perumahan dengan rumah subsidi yang terdaftar di Kementerian PUPR dan telah dibangun sejak tahun 2010 atau setelahnya, yaitu saat program rumah subsidi dengan skema KPR-FLPP telah dilaksanakan secara nasional oleh pemerintah.

2. Perumahan dengan rumah subsidi yang dikembangkan oleh developer berizin dan sudah dikenal oleh masyarakat Kota Kupang.

3. Rumah subsidi memiliki elemen-elemen rumah yang telah dikembangkan, seperti: ruang dalam rumah, ruang luar rumah, dan/atau fasad rumah.

\section{Hasil dan Pembahasan}

\section{Deskripsi Lokasi dan Objek Penelitian}

Dari beberapa perumahan subsidi yang terdapat di Kota Kupang, dipilih tiga perumahan dari tiga pengembang menurut kriteria yang telah dijelaskan di bagian metode penelitian. Perumahan tersebut yaitu: (1) Perumahan Gemstone Regency (Pengembang PT. Charson Timorland); (2) Perumahan Bello Royal Residence (Pengembang PT. Putra Tunggal Mentari); dan (3) Perumahan Pondok Indah Matani (Pengembang PT. Pembangunan Sehat Sejahtera).

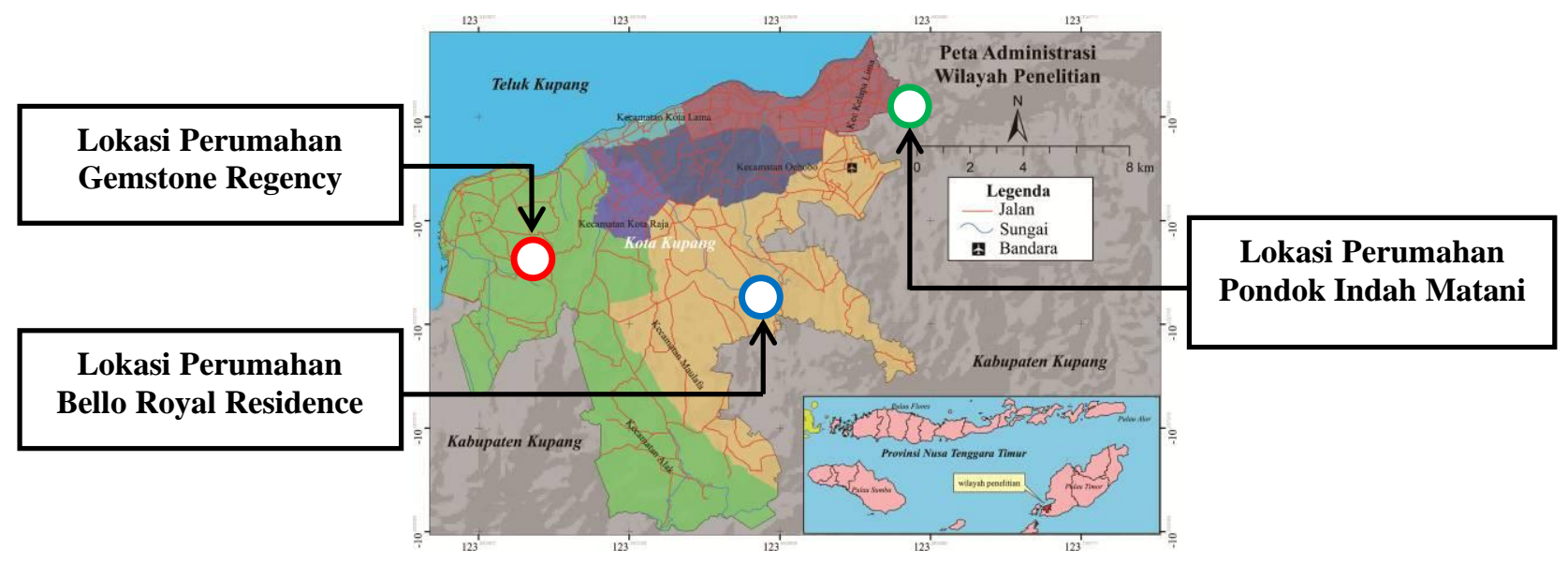

Gambar 1. Lokasi Perumahan (Objek Penelitian)

Sumber: BPS, 2015; Dokumentasi, 2020

\section{A. Kondisi perumahan dan rumah subsidi di Perumahan Gemstone Regency}

Perumahan Gemstone Regency terletak di bagian barat Kota Kupang, tepatnya di Kelurahan Penkase Oeleta, Kecamatan Alak, Kota Kupang, NTT. Perumahan ini dikembangkan oleh PT. Charson Timorland dengan jumlah rumah subsidi mencapai \pm 500 unit. Rumah subsidi di Perumahan Gemstone Regency memiliki tipe 30/96 kopel, yang terdiri dari teras depan, 2 ruang tidur, ruang tamu yang menyatu dengan ruang keluarga, 1 kamar mandi/WC, halaman depan dan halaman belakang. Halaman depan dan halaman belakang disediakan untuk dikembangkan oleh penghuni secara mandiri. 


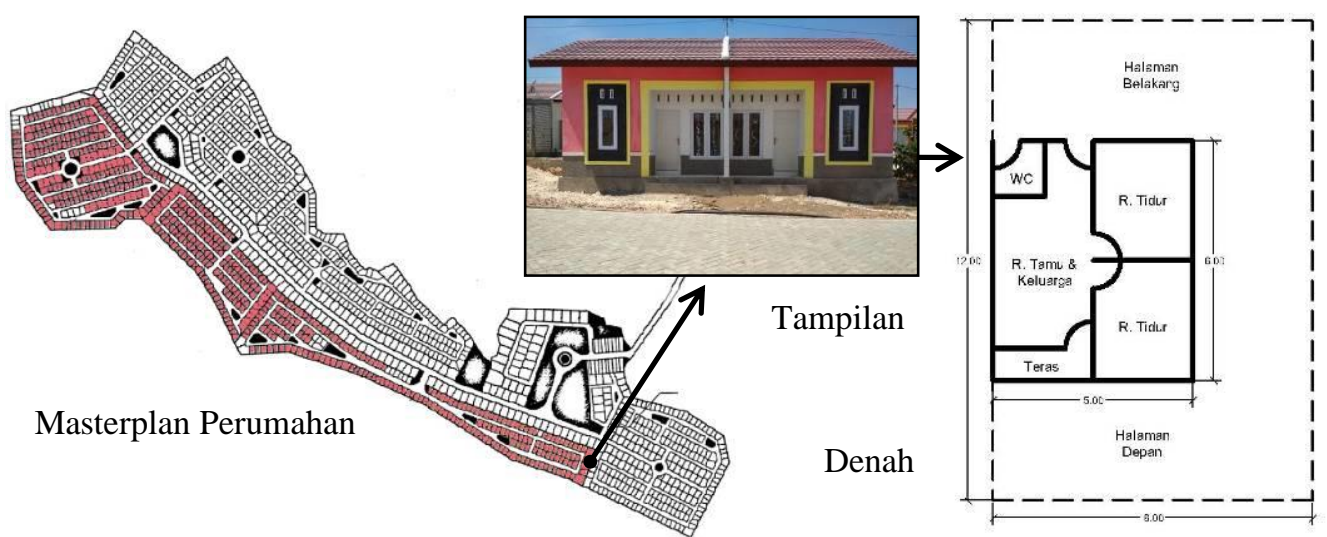

Gambar 2. Masterplan, Denah, Dan I'ampilan Kumah Subsidi Di Perumahan Gemstone Regency Sumber: Kementerian PUPR, 2020; Dokumentasi, 2020

\section{B. Kondisi perumahan dan rumah subsidi di Perumahan Bello Royal Residence}

Perumahan Bello Royal Residence terletak di bagian tengah Kota Kupang, tepatnya di Kelurahan Bello, Kecamatan Maulafa, Kota Kupang, NTT. Perumahan ini dikembangkan oleh PT. Putra Tunggal Mentari dengan jumlah rumah subsidi mencapai \pm 80 unit. Rumah subsidi di Perumahan Bello Royal Residence memiliki tipe 36/91, yang terdiri dari teras depan, 2 ruang tidur, 1 ruang tamu, 1 ruang keluarga yang menyatu dengan ruang makan, 1 kamar mandi/WC, halaman depan dan halaman belakang. Halaman depan dan halaman belakang disediakan untuk dikembangkan oleh penghuni secara mandiri.

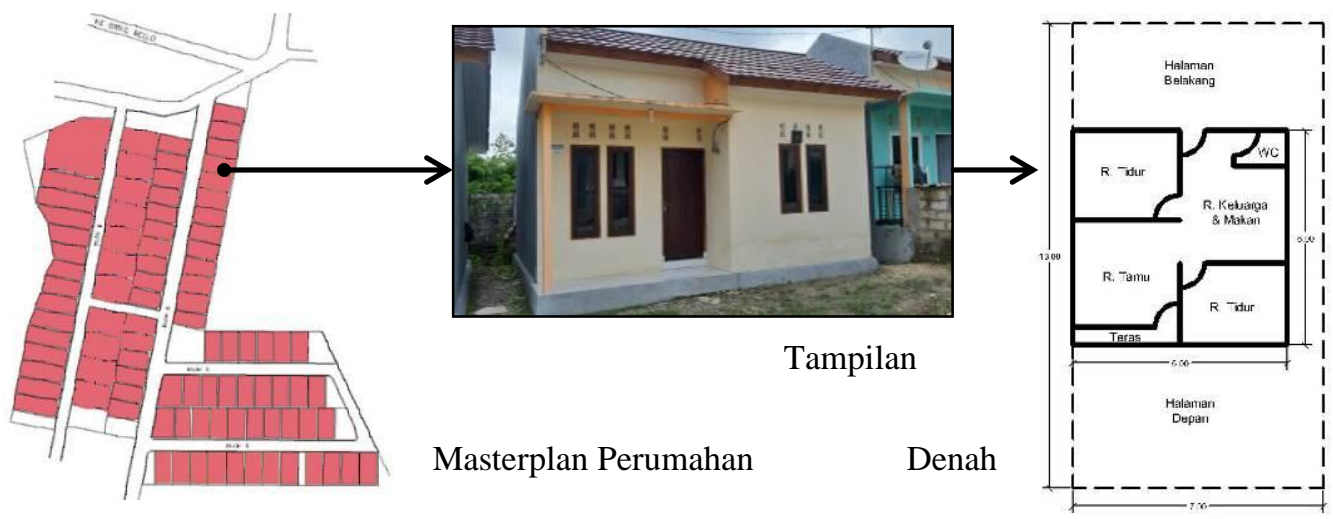

Gambar 3. Masterplan, Denah, Dan Tampilan Rumah Subsidi Di Perumahan Bello Royal Residence Sumber: Kementerian PUPR, 2020; Dokumentasi, 2020

\section{Kondisi perumahan dan rumah subsidi di Perumahan Pondok Indah Matani}

Perumahan Pondok Indah Matani terletak di bagian timur perbatasan Kota Kupang, tepatnya di Desa Penfui Timur, Kecamatan Kupang Tengah, Kabupaten Kupang, NTT. Perumahan ini dikembangkan oleh PT. Pembangunan Sehat Sejahtera dengan jumlah rumah subsidi mencapai \pm 350 unit. Rumah subsidi di Perumahan Pondok Indah Matani memiliki tipe 30/105, yang terdiri dari teras depan, 2 ruang tidur, 1 ruang tamu yang menyatu dengan ruang keluarga, 1 dapur, 1 kamar mandi/WC, halaman depan dan halaman belakang. Halaman depan dan halaman belakang disediakan untuk dikembangkan oleh penghuni secara mandiri. 


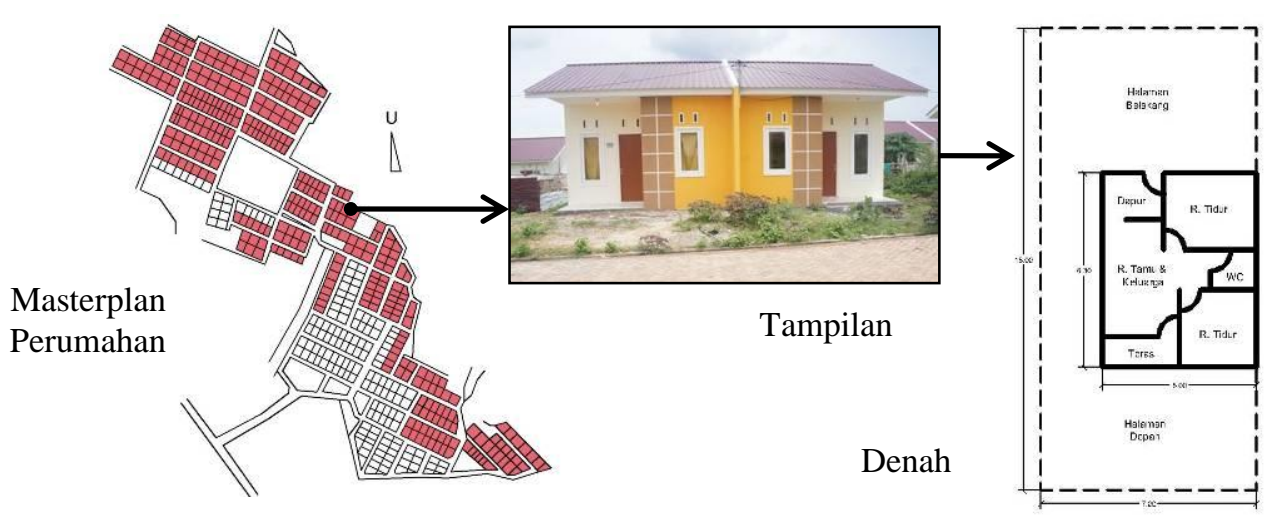

Gambar 4. Masterplan, denah, dan tampilan rumah subsidi di Perumahan Pondok Indah Matani Sumber: Kementerian PUPR, 2020; Dokumentasi, 2020

\section{Tipologi Pengembangan Rumah Subsidi di Kota Kupang}

\section{A. Pengkodean dan kategorisasi pengembangan rumah subsidi}

Berdasarkan tiga perumahan subsidi yang telah diobservasi, masing-masing perumahan diberikan kode untuk memudahkan identifikasi, yaitu: Perumahan Gemstone Regency berkode A (15 sampel), Perumahan Bello Royal Residence berkode B (10 sampel), dan Perumahan Pondok Indah Matani berkode C (15 sampel). Sampel rumah yang telah dikumpulkan selanjutnya dikategorisasi menurut elemen rumah subsidi dan aspek pembentuk elemen pengembangan rumah subsidi. Pengembangan pada tatanan rumah, dapat dibagi menjadi tiga macam, yaitu: (1) penambahan elemen/ruang pada rumah (kode T1), jika penghuni melakukan penambahan elemen/ruang pada ruang dalam, ruang luar, atau fasad rumah tanpa melakukan perubahan signifikan pada kondisi eksistingnya; (2) penggabungan elemen/ruang pada rumah (kode T2), jika penghuni melakukan penggabungan beberapa elemen/ruang pada ruang dalam, ruang luar, atau fasad rumah menjadi satu elemen/ruang sehingga terdapat elemen/ruang yang berkurang; dan (3) perubahan elemen/ruang pada rumah (kode T3), jika penghuni melakukan perubahan elemen/ruang menjadi elemen/ruang baru yang berbeda dengan kondisi eksistingnya.

Pengembangan pada material rumah, dapat dibagi menjadi dua macam, yaitu: (1) penambahan material pada rumah (kode M1), jika penghuni menambahkan material baru pada ruang dalam, ruang luar, atau fasad rumah dengan tetap mempertahankan material eksistingnya; dan (2) penggantian material pada rumah (kode M2), jika penghuni mengganti secara signifikan material eksisting dengan material baru pada ruang dalam, ruang luar, atau fasad rumah. Pengembangan pada warna rumah, dapat dibagi menjadi dua macam, yaitu: (1) penambahan warna pada rumah (kode W1), jika penghuni menambahkan warna baru pada ruang dalam, ruang luar, atau fasad rumah dengan tetap mempertahankan warna eksistingnya; dan (2) penggantian warna pada rumah (kode W2), jika penghuni mengganti secara signifikan warna eksisting dengan warna baru pada ruang dalam, ruang luar, atau fasad rumah. Sementara itu, pengembangan pada ragam hias dilakukan jika penghuni melakukan penambahan ragam hias (kode R) pada ruang dalam, ruang luar, atau fasad rumahnya.

Tabel 1. Kategorisasi Pengembangan

\begin{tabular}{clcccc}
\hline \multirow{2}{*}{$\begin{array}{c}\text { Sampel dan } \\
\text { Elemen }\end{array}$} & \multicolumn{5}{c}{ Aspek Pembentuk Elemen } \\
\cline { 3 - 6 } & Tatanan & Material & Warna & $\begin{array}{c}\text { Ragam } \\
\text { Hias }\end{array}$ \\
\hline \multirow{2}{*}{ A1 } & R. Dalam & T1 & - & - & - \\
\cline { 2 - 6 } & R. Luar & T3 & - & W2 & - \\
\cline { 2 - 6 } & Fasad & - & - & W2 & - \\
\hline A2 & R. Dalam & T1 & - & - & - \\
\hline
\end{tabular}

\begin{tabular}{clccccc}
\hline \multirow{2}{*}{} & R. Luar & T3 & - & W2 & - \\
\cline { 2 - 6 } & Fasad & - & - & W2 & - \\
\hline \multirow{2}{*}{ A3 } & R. Dalam & T1, T3 & - & W2 & - \\
\cline { 2 - 6 } & R. Luar & T3 & M1 & W2 & R \\
\cline { 2 - 6 } & Fasad & T1 & M1 & W2 & R \\
\hline \multirow{2}{*}{ A4 } & R. Dalam & T1, T2, T3 & - & W2 & - \\
\cline { 2 - 6 } & R. Luar & T3 & M1 & W2 & R \\
\hline
\end{tabular}




\begin{tabular}{|c|c|c|c|c|c|}
\hline & Fasad & $\mathrm{T} 1$ & - & W2 & - \\
\hline \multirow{3}{*}{ A5 } & R. Dalam & $\mathrm{T} 1$ & - & - & - \\
\hline & R. Luar & $\mathrm{T} 3$ & - & - & - \\
\hline & Fasad & - & - & - & - \\
\hline \multirow{3}{*}{ A6 } & R. Dalam & $\mathrm{T} 1, \mathrm{~T} 2$ & - & W2 & - \\
\hline & R. Luar & $\mathrm{T} 3$ & - & W2 & - \\
\hline & Fasad & $\mathrm{T} 1$ & - & W2 & - \\
\hline \multirow{3}{*}{ A7 } & R. Dalam & $\mathrm{T} 1, \mathrm{~T} 3$ & - & - & - \\
\hline & R. Luar & $\mathrm{T} 3$ & - & $\mathrm{W} 1$ & - \\
\hline & Fasad & $\mathrm{T} 1$ & - & W1 & - \\
\hline \multirow{3}{*}{ A8 } & R. Dalam & $\mathrm{T} 1$ & - & W2 & - \\
\hline & R. Luar & $\mathrm{T} 3$ & - & W2 & - \\
\hline & Fasad & $\mathrm{T} 1$ & - & $\mathrm{W} 2$ & - \\
\hline \multirow{3}{*}{ A9 } & R. Dalam & $\mathrm{T} 1, \mathrm{~T} 2$ & - & - & - \\
\hline & R. Luar & $\mathrm{T} 3$ & M1 & W2 & $\mathrm{R}$ \\
\hline & Fasad & $\mathrm{T} 1$ & - & $\mathrm{W} 2$ & - \\
\hline \multirow{3}{*}{ A 10} & R. Dalam & $\mathrm{T} 1$ & - & $\mathrm{W} 1$ & - \\
\hline & R. Luar & $\mathrm{T} 3$ & M1 & W2 & $\mathrm{R}$ \\
\hline & Fasad & $\mathrm{T} 1$ & - & $\mathrm{W} 2$ & - \\
\hline \multirow{3}{*}{ A11 } & R. Dalam & $\mathrm{T} 1$ & - & $\mathrm{W} 1$ & - \\
\hline & R. Luar & $\mathrm{T} 3$ & M1 & W2 & $\mathrm{R}$ \\
\hline & Fasad & $\mathrm{T} 1$ & - & W2 & - \\
\hline \multirow{3}{*}{ A 12} & R. Dalam & $\mathrm{T} 1$ & - & - & - \\
\hline & R. Luar & $\mathrm{T} 3$ & M1 & W2 & $\mathrm{R}$ \\
\hline & Fasad & $\mathrm{T} 1$ & - & $\mathrm{W} 2$ & - \\
\hline \multirow{3}{*}{ A 13} & R. Dalam & $\mathrm{T} 1$ & - & - & - \\
\hline & R. Luar & $\mathrm{T} 3$ & - & W2 & - \\
\hline & Fasad & $\mathrm{T} 1$ & - & W2 & - \\
\hline \multirow{3}{*}{ A14 } & R. Dalam & $\mathrm{T} 1$ & - & - & - \\
\hline & R. Luar & $\mathrm{T} 3$ & M1 & W1 & $\mathrm{R}$ \\
\hline & Fasad & $\mathrm{T} 1$ & - & W2 & - \\
\hline \multirow{3}{*}{ A 15} & R. Dalam & $\mathrm{T} 1$ & - & - & - \\
\hline & R. Luar & $\mathrm{T} 3$ & M1 & $\mathrm{W} 2$ & $\mathrm{R}$ \\
\hline & Fasad & $\mathrm{T} 1$ & - & W2 & - \\
\hline \multirow{3}{*}{ B1 } & R. Dalam & $\mathrm{T} 1, \mathrm{~T} 2$ & - & $\mathrm{W} 2$ & - \\
\hline & R. Luar & $\mathrm{T} 3$ & M1 & W2 & $\mathrm{R}$ \\
\hline & Fasad & $\mathrm{T} 1$ & M1 & W2 & $\mathrm{R}$ \\
\hline \multirow{3}{*}{ B2 } & R. Dalam & $\mathrm{T} 1$ & - & $\mathrm{W} 2$ & - \\
\hline & R. Luar & $\mathrm{T} 3$ & M1 & W2 & $\mathrm{R}$ \\
\hline & Fasad & $\mathrm{T} 1$ & - & W1 & - \\
\hline \multirow{3}{*}{ B3 } & R. Dalam & $\mathrm{T} 1, \mathrm{~T} 2$ & - & - & - \\
\hline & R. Luar & $\mathrm{T} 3$ & M1 & W2 & $\mathrm{R}$ \\
\hline & Fasad & $\mathrm{T} 1$ & - & $\mathrm{W} 1$ & - \\
\hline \multirow{3}{*}{ B4 } & R. Dalam & $\mathrm{T} 1$ & - & $\mathrm{W} 2$ & - \\
\hline & R. Luar & $\mathrm{T} 3$ & M1 & W2 & $\mathrm{R}$ \\
\hline & Fasad & $\mathrm{T} 1$ & - & W2 & - \\
\hline \multirow{2}{*}{ B5 } & R. Dalam & $\mathrm{T} 1, \mathrm{~T} 2$ & - & W2 & - \\
\hline & R. Luar & $\mathrm{T} 3$ & M1 & W2 & $\mathrm{R}$ \\
\hline
\end{tabular}

\begin{tabular}{|c|c|c|c|c|c|}
\hline & Fasad & $\mathrm{T} 1$ & - & W1 & - \\
\hline \multirow{3}{*}{ B6 } & R. Dalam & $\mathrm{T} 1$ & - & - & - \\
\hline & R. Luar & $\mathrm{T} 3$ & - & W2 & - \\
\hline & Fasad & $\mathrm{T} 1$ & - & W2 & - \\
\hline \multirow{3}{*}{ B7 } & R. Dalam & $\mathrm{T} 1$ & - & $\mathrm{W} 2$ & - \\
\hline & R. Luar & $\mathrm{T} 3$ & M1 & W2 & $\mathrm{R}$ \\
\hline & Fasad & $\mathrm{T} 1$ & - & W2 & - \\
\hline \multirow{3}{*}{ B8 } & R. Dalam & $\mathrm{T} 1$ & - & W2 & - \\
\hline & R. Luar & $\mathrm{T} 3$ & M1 & W2 & $\mathrm{R}$ \\
\hline & Fasad & $\mathrm{T} 1$ & - & W2 & - \\
\hline \multirow{3}{*}{ B9 } & R. Dalam & $\mathrm{T} 1$ & - & $\mathrm{W} 2$ & - \\
\hline & R. Luar & $\mathrm{T} 3$ & M1 & W2 & $\mathrm{R}$ \\
\hline & Fasad & $\mathrm{T} 1$ & - & W2 & - \\
\hline \multirow{3}{*}{ B10 } & R. Dalam & $\mathrm{T} 1$ & - & $\mathrm{W} 2$ & - \\
\hline & R. Luar & $\mathrm{T} 3$ & M1 & W2 & $\mathrm{R}$ \\
\hline & Fasad & $\mathrm{T} 1$ & - & $\mathrm{W} 2$ & - \\
\hline \multirow{3}{*}{$\mathrm{C} 1$} & R. Dalam & $\mathrm{T} 1$ & - & - & - \\
\hline & R. Luar & $\mathrm{T} 3$ & - & $\mathrm{W} 2$ & - \\
\hline & Fasad & $\mathrm{T} 1$ & - & W2 & - \\
\hline \multirow{3}{*}{$\mathrm{C} 2$} & R. Dalam & $\mathrm{T} 1$ & - & $\mathrm{W} 2$ & - \\
\hline & R. Luar & $\mathrm{T} 3$ & M1 & $\mathrm{W} 2$ & $\mathrm{R}$ \\
\hline & Fasad & $\mathrm{T} 1$ & - & W1 & - \\
\hline \multirow{3}{*}{$\mathrm{C} 3$} & R. Dalam & $\mathrm{T} 1, \mathrm{~T} 2$ & - & $\mathrm{W} 2$ & - \\
\hline & R. Luar & $\mathrm{T} 3$ & M1 & W2 & $\mathrm{R}$ \\
\hline & Fasad & $\mathrm{T} 1$ & - & W1 & - \\
\hline \multirow{3}{*}{$\mathrm{C} 4$} & R. Dalam & $\mathrm{T} 1, \mathrm{~T} 2, \mathrm{~T} 3$ & - & $\mathrm{W} 2$ & - \\
\hline & R. Luar & $\mathrm{T} 3$ & - & $\mathrm{W} 2$ & - \\
\hline & Fasad & - & - & W2 & - \\
\hline \multirow{3}{*}{$\mathrm{C} 5$} & R. Dalam & $\mathrm{T} 1$ & - & - & - \\
\hline & R. Luar & $\mathrm{T} 3$ & M1 & W2 & $\mathrm{R}$ \\
\hline & Fasad & $\mathrm{T} 1$ & - & W2 & - \\
\hline \multirow{3}{*}{ C6 } & R. Dalam & $\mathrm{T} 1$ & - & - & - \\
\hline & R. Luar & T3 & - & $\mathrm{W} 2$ & - \\
\hline & Fasad & $\mathrm{T} 1$ & $\mathrm{~T} 1$ & $\mathrm{~W} 2$ & - \\
\hline \multirow{3}{*}{$\mathrm{C} 7$} & R. Dalam & $\mathrm{T} 1$ & - & W2 & - \\
\hline & R. Luar & $\mathrm{T} 3$ & - & W2 & - \\
\hline & Fasad & $\mathrm{T} 1$ & - & W2 & - \\
\hline \multirow{3}{*}{$\mathrm{C} 8$} & R. Dalam & $\mathrm{T} 1, \mathrm{~T} 2$ & - & - & - \\
\hline & R. Luar & T3 & M1 & W2 & $\mathrm{R}$ \\
\hline & Fasad & $\mathrm{T} 1$ & - & W1 & - \\
\hline \multirow{3}{*}{ C9 } & R. Dalam & $\mathrm{T} 1$ & - & - & - \\
\hline & R. Luar & $\mathrm{T} 3$ & - & W2 & - \\
\hline & Fasad & $\mathrm{T} 1$ & - & W2 & - \\
\hline \multirow{3}{*}{$\mathrm{C} 10$} & R. Dalam & $\mathrm{T} 1$ & - & - & - \\
\hline & R. Luar & $\mathrm{T} 3$ & M1 & $\mathrm{W} 2$ & $\mathrm{R}$ \\
\hline & Fasad & $\mathrm{T} 1$ & M1 & $\mathrm{W} 2$ & $\mathrm{R}$ \\
\hline \multirow{2}{*}{$\mathrm{C} 11$} & R. Dalam & $\mathrm{T} 1, \mathrm{~T} 3$ & - & - & - \\
\hline & R. Luar & $\mathrm{T} 3$ & M1 & W2 & $\mathrm{R}$ \\
\hline
\end{tabular}




\begin{tabular}{lllccc}
\hline \multirow{2}{*}{ C12 } & Fasad & T1 & - & W1 & - \\
\cline { 2 - 6 } & R. Dalam & T1 & - & - & - \\
\cline { 2 - 6 } & R. Luar & T3 & M1 & W2 & R \\
\cline { 2 - 6 } & Fasad & T1 & - & W2 & - \\
\hline \multirow{2}{*}{ C13 } & R. Dalam & T1 & - & - & - \\
\cline { 2 - 6 } & R. Luar & T3 & M1 & W2 & R \\
\cline { 2 - 6 } & Fasad & T1 & - & W1 & - \\
\hline C14 & R. Dalam & T1, T2, T3 & - & - & - \\
\hline
\end{tabular}

\begin{tabular}{cllccc}
\hline \multirow{2}{*}{} & R. Luar & T3 & - & W2 & - \\
\cline { 2 - 6 } & Fasad & T1 & M1 & W2 & R \\
\hline \multirow{2}{*}{ C15 } & R. Dalam & T1 & - & - & - \\
\cline { 2 - 6 } & R. Luar & T3 & - & W2 & - \\
\cline { 2 - 6 } & Fasad & T1 & - & W2 & - \\
\hline
\end{tabular}

Keterangan Kode Tabel 1:

A1-A15: Sampel rumah di Perumahan 1.

B1-B15: Sampel rumah di Perumahan 2.

C1-C15: Sampel rumah di Perumahan 3.

T1: Penambahan elemen/ruang (terdapat penambahan jumlah elemen/ruang).

T2: Penggabungan elemen/ruang (terdapat elemen/ruang yang digabung menjadi satu).

T3: Perubahan elemen/ruang (terdapat elemen/ruang yang berubah).

M1: Penambahan material (menambah material baru pada material lama).

M2: Penggantian material (mengganti dengan material baru secara keseluruhan).

W1: Penambahan warna (menambah warna baru pada warna lama).

W2: Penggantian warna (mengganti dengan warna baru secara keseluruhan).

$\mathrm{R}$ : Penambahan ragam hias (ornamen atau dekorasi).

\section{B. Jumlah penerapan aspek-aspek pembentuk elemen pengembangan rumah subsidi}

Berdasarkan hasil kategorisasi aspek pembentuk elemen pengembangan rumah subsidi dapat dihitung jumlah penerapannya pada tiap-tiap elemen rumah dan dapat dilihat kecenderungan aspek pembentuk elemen pengembangan yang paling dominan dilakukan penghuni pada setiap elemen maupun secara keseluruhan. Hal ini dapat dijadikan salah satu acuan dalam merumuskan tipe pengembangan rumah subsidi oleh penghuni di Kota Kupang, NTT.

Berdasarkan aspek tatanan rumah, dapat dipahami bahwa pada ruang dalam, seluruh penghuni melakukan penambahan ruang baru pada rumah (T1) yaitu mencapai $100 \%$ dari seluruh sampel rumah, sedangkan melakukan penggabungan ruang (T2) sebesar 25\% dan perubahan ruang (T3) sebesar $15 \%$. Berdasarkan data tersebut dapat dipahami pula bahwa terdapat penghuni yang melakukan kombinasi penambahan, penggabungan dan/atau perubahan dalam satu rumah, meskipun jumlahnya tidak signifikan. Pada ruang luar, seluruh penghuni melakukan perubahan ruang (T3) yaitu dengan persentase $100 \%$, sedangkan pada fasad rumahnya seluruh penghuni secara dominan melakukan penambahan elemen (T1) yaitu mencapai 90\% dari seluruh sampel rumah.

Berdasarkan aspek material rumah, dapat dipahami bahwa pada ruang dalam, penghuni tidak melakukan penambahan (M1) atau penggantian material (M2) sehingga masih sama dengan kondisi eksistingnya. Pada ruang luar, penghuni melakukan penambahan material (M1) secara signifikan yaitu mencapai $67,5 \%$ dari seluruh sampel rumah, sedangkan pada fasad rumahnya, penghuni melakukan penambahan material (M1) meskipun tidak signifikan yaitu hanya mencapai $10 \%$ dari seluruh sampel rumah.

Berdasarkan aspek warna rumah, dapat dipahami bahwa secara signifikan penghuni rumah melakukan penggantian warna (W2) pada ruang dalam, ruang luar dan fasad rumahnya. Pada ruang dalam, penggantian warna (W2) dilakukan sebanyak 40\%, sedangkan penambahan warna (W1) hanya 5\% dari seluruh sampel rumah, sehingga terdapat 55\% sampel rumah yang masih sesuai dengan kondisi eksisting. Pada ruang luar, penggantian warna (W2) mencapai 92,5\%, sedangkan penambahan warna (W1) hanya $5 \%$ dari seluruh sampel rumah, sehingga terdapat $2,5 \%$ sampel 
rumah yang masih sesuai dengan kondisi eksisting. Sementara itu, pada fasad rumah, penggantian warna (W2) mencapai 72,5\% dan penambahan warna (W1) mencapai 22,5\% dari seluruh sampel rumah, sehingga terdapat $5 \%$ sampel rumah yang masih sesuai dengan kondisi eksistingnya.

Berdasarkan aspek ragam hias pada rumah, dapat dipahami bahwa penambahan ragam hias (R) hanya dilakukan pada ruang luar dan fasad rumah. Penambahan ragam hias (R) paling signifikan dilakukan di ruang luar yang mencapai $62,5 \%$, sedangkan pada fasad rumah hanya mencapai $10 \%$ dari seluruh sampel rumah.

Berdasarkan hasil perhitungan persentase aspek-aspek pembentuk elemen pengembangan rumah untuk tiap-tiap elemen, maka dapat dipahami bahwa terdapat beberapa aspek pembentuk elemen yang persentasenya kurang signifikan yaitu kurang dari 20\% (kurang dari 8-unit rumah). Oleh karena itu, dalam merumuskan tipe-tipe pengembangan rumah subsidi, hanya difokuskan pada aspek-aspek pembentuk elemen pengembangan yang diterapkan secara signifikan oleh penghuni. Dengan demikian, dapat diperoleh tipe-tipe pengembangan rumah subsidi yang dapat mewakili kasus yang lebih banyak dan cakupan wilayah yang lebih luas.

Tabel 2. Persentase Aspek Pembentuk Elemen Pengembangan Rumah Subsidi

\begin{tabular}{|c|c|c|c|c|c|c|c|c|}
\hline \multirow{3}{*}{ Elemen Rumah } & \multicolumn{8}{|c|}{ Aspek Pembentuk Elemen Pengembangan (\%) } \\
\hline & \multicolumn{3}{|c|}{ Tatanan } & \multicolumn{2}{|c|}{ Material } & \multicolumn{2}{|c|}{ Warna } & \multirow{2}{*}{$\begin{array}{c}\text { Ragam Hias } \\
\text { (R) }\end{array}$} \\
\hline & $\mathbf{T 1}$ & $\mathbf{T 2}$ & T3 & M1 & M2 & W1 & W2 & \\
\hline R. Dalam & 100 & 25 & 15 & 0 & 0 & 5 & 40 & 0 \\
\hline R. Luar & 0 & 0 & 100 & 67,5 & 0 & 5 & 92,5 & 62,5 \\
\hline Fasad & 90 & 0 & 0 & 10 & 0 & 22,5 & 72,5 & 10 \\
\hline
\end{tabular}

Sumber: Analisis, 2020

\section{Tipe-tipe pengembangan rumah subsidi}

Berdasarkan hasil kategorisasi dan perhitungan persentase pengembangan rumah subsidi, dapat dipahami bahwa terdapat beberapa aspek pembentuk elemen pengembangan rumah yang diterapkan secara signifikan (persentase $\geq 20 \%$ ) pada tiap-tiap elemen rumah, yaitu: (1) aspek pembentuk elemen pada ruang dalam meliputi T1, T2 dan W2; (2) aspek pembentuk elemen pada ruang luar meliputi T3, M1, W2 dan R; serta (3) aspek pembentuk elemen pada fasad rumah meliputi T1, W1 dan W2. Dengan demikian, dapat dirumuskan sembilan tipe pengembangan rumah subsidi oleh penghuni di Kota Kupang, NTT, yaitu:

1. Tipe 1 yaitu pengembangan rumah subsidi dengan penambahan dan penggabungan ruang (T1 + T2) dan penggantian warna (W2) pada ruang dalam; ditambah perubahan ruang (T3), penambahan material (M1), penggantian warna (W2) dan penambahan ragam hias (R) pada ruang luar; serta penambahan elemen (T1) dan penambahan warna (W1) pada fasad rumah. Diterapkan sebanyak 5\% dari seluruh sampel rumah.

2. Tipe 2 yaitu pengembangan rumah subsidi dengan penambahan dan penggabungan ruang (T1 + T2) pada ruang dalam; ditambah perubahan ruang (T3), penambahan material (M1), penggantian warna (W2) dan penambahan ragam hias (R) pada ruang luar; serta penambahan elemen (T1) dan penggantian warna (W2) pada fasad rumah. Diterapkan sebanyak 5\% dari seluruh sampel rumah.

3. Tipe 3 yaitu pengembangan rumah subsidi dengan penambahan ruang (T1) dan penggantian warna (W2) pada ruang dalam; ditambah perubahan ruang (T3), penambahan material (M1), penggantian warna (W2) dan penambahan ragam hias (R) pada ruang luar; serta penambahan elemen (T1) dan penambahan warna (W1) pada fasad rumah. Diterapkan sebanyak 5\% dari seluruh sampel rumah. 
4. Tipe 4 yaitu pengembangan rumah subsidi dengan penambahan ruang (T1) dan penggantian warna (W2) pada ruang dalam; ditambah perubahan ruang (T3), penambahan material (M1), penggantian warna (W2) dan penambahan ragam hias (R) pada ruang luar; serta penambahan elemen (T1) dan penggantian warna (W2) pada fasad rumah. Diterapkan sebanyak $17,5 \%$ dari seluruh sampel rumah.

5. Tipe 5 yaitu pengembangan rumah subsidi dengan penambahan ruang (T1) dan penggantian warna (W2) pada ruang dalam; ditambah perubahan ruang (T3) dan penggantian warna (W2) pada ruang luar; serta penambahan elemen (T1) dan penggantian warna (W2) pada fasad rumah. Diterapkan sebanyak 5\% dari seluruh sampel rumah.

6. Tipe 6 yaitu pengembangan rumah subsidi dengan penambahan ruang (T1) pada ruang dalam; ditambah perubahan ruang (T3), penambahan material (M1), penggantian warna (W2) dan penambahan ragam hias $(\mathrm{R})$ pada ruang luar; serta penambahan elemen (T1) dan penambahan warna (W1) pada fasad rumah. Diterapkan sebanyak 5\% dari seluruh sampel rumah.

7. Tipe 7 yaitu pengembangan rumah subsidi dengan penambahan ruang (T1) pada ruang dalam; ditambah perubahan ruang (T3), penambahan material (M1), penggantian warna (W2) dan penambahan ragam hias (R) pada ruang luar; serta penambahan elemen (T1) dan penggantian warna (W2) pada fasad rumah. Diterapkan sebanyak 15\% dari seluruh sampel rumah.

8. Tipe 8 yaitu pengembangan rumah subsidi dengan penambahan ruang (T1) pada ruang dalam; ditambah perubahan ruang (T3) dan penggantian warna (W2) pada ruang luar; serta penambahan elemen (T1) dan penggantian warna (W2) pada fasad rumah. Diterapkan sebanyak $15 \%$ dari seluruh sampel rumah.

9. Tipe 9 yaitu pengembangan rumah subsidi dengan penambahan ruang (T1) pada ruang dalam; ditambah perubahan ruang (T3) dan penggantian warna (W2) pada ruang luar; serta penggantian warna (W2) pada fasad rumah. Diterapkan sebanyak 5\% dari seluruh sampel rumah.

Apabila kesembilan tipe pengembangan rumah subsidi tersebut direduksi kembali dengan mempertimbangkan persentase penerapan tipe mencapai lebih $10 \%$ dari seluruh sampel rumah, maka diperoleh tiga tipe pengembangan rumah subsidi oleh penghuni di Kota Kupang, NTT, yaitu:

1. Tipe 1 yaitu pengembangan rumah subsidi dengan penambahan ruang (T1) dan penggantian warna (W2) pada ruang dalam; ditambah perubahan ruang (T3), penambahan material (M1), penggantian warna (W2) dan penambahan ragam hias (R) pada ruang luar; serta penambahan elemen (T1) dan penggantian warna (W2) pada fasad rumah.

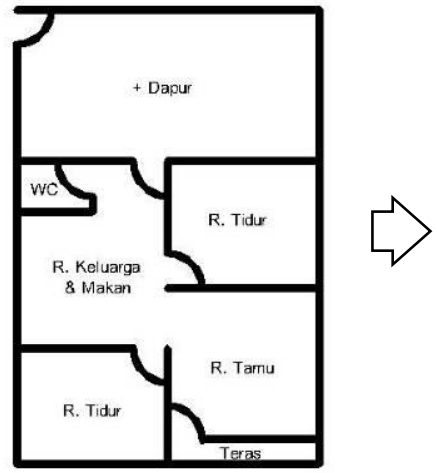

Denah (B4)

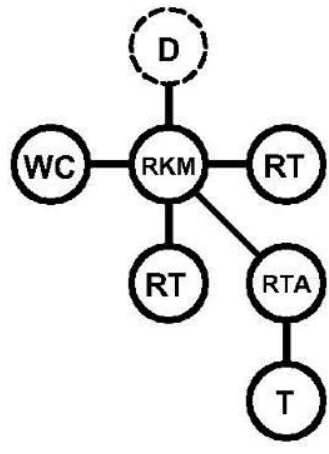

Organisasi ruang (B4)

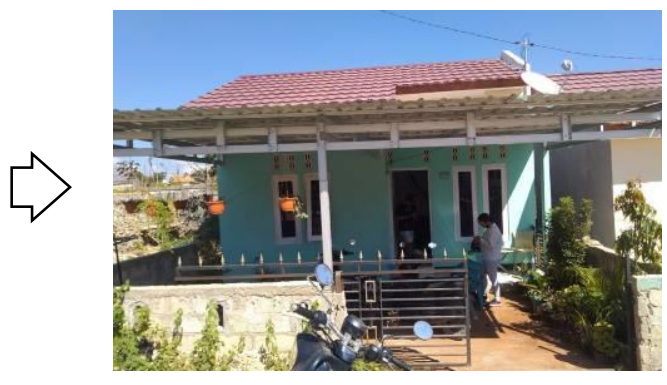

Tampilan rumah (B4)

Gambar 5. Contoh Pengembangan Rumah Tipe 1 Yang Teridentifikasi Di Beberapa Sampel Rumah Sumber: Analisis, 2020 
2. Tipe 2 yaitu pengembangan rumah subsidi dengan penambahan ruang (T1) pada ruang dalam; ditambah perubahan ruang (T3), penambahan material (M1), penggantian warna (W2) dan penambahan ragam hias $(\mathrm{R})$ pada ruang luar; serta penambahan elemen (T1) dan penggantian warna (W2) pada fasad rumah.

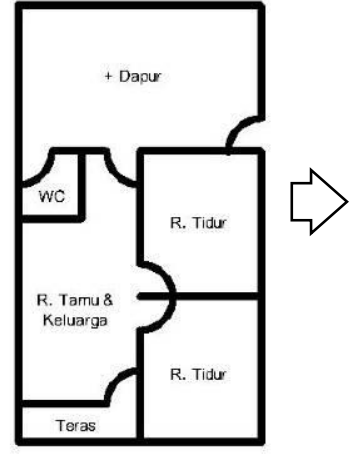

Denah (A12)

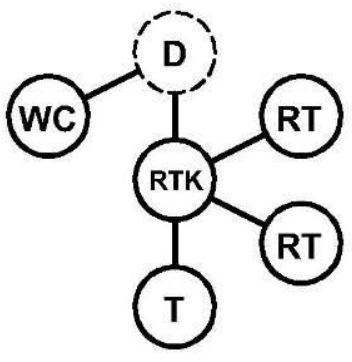

Organisasi ruang (A12)

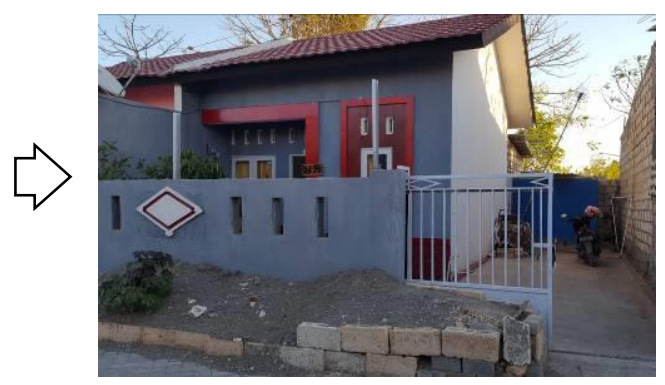

Tampilan rumah (A12)

Gambar 6. Contoh Pengembangan Rumah Tipe 2 Yang Teridentifikasi Di Beberapa Sampel Rumah Sumber: Analisis, 2020

3. Tipe 3 yaitu pengembangan rumah subsidi dengan penambahan ruang (T1) pada ruang dalam; ditambah perubahan ruang (T3) dan penggantian warna (W2) pada ruang luar; serta penambahan elemen (T1) dan penggantian warna (W2) pada fasad rumah.

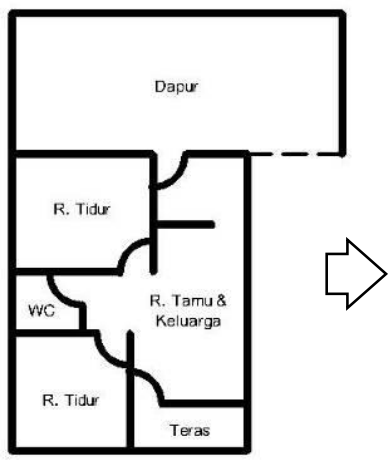

Denah $(\mathrm{C} 1)$

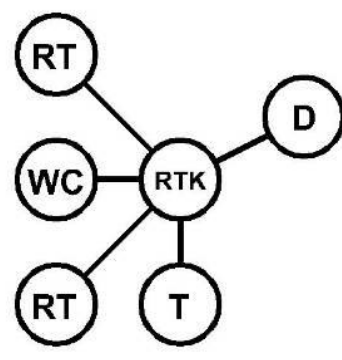

Organisasi ruang $(\mathrm{C} 1)$

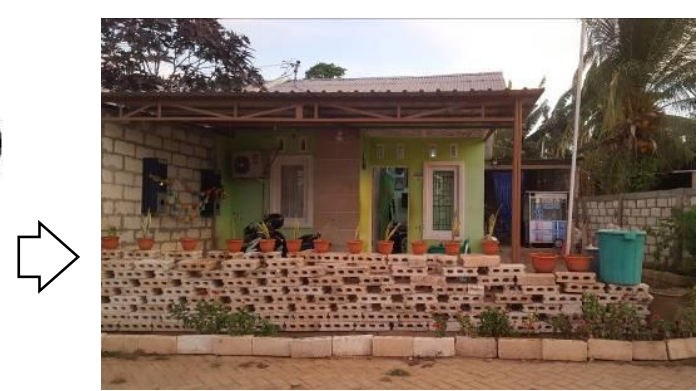

Tampilan rumah $(\mathrm{C} 1)$

Gambar 7. Pengembangan Rumah Tipe 3 Yang Teridentifikasi Di Beberapa Sampel Rumah Sumber: Analisis, 2020

Tipe-tipe pengembangan rumah subsidi oleh penghuni di Kota Kupang memperlihatkan bahwa penghuni rumah sebagian besar melakukan penambahan ruang baru pada ruang dalam rumah. Penambahan ruang tersebut diantaranya: dapur, ruang makan, ruang tidur dan kamar mandi/WC. Penggantian warna pada ruang dalam juga banyak dilakukan oleh penghuni dengan warna yang berbeda dengan warna eksistingnya. Warna yang banyak dipilih adalah warna-warna cerah, seperti: krem, hijau dan biru. Pada ruang luar, penghuni sebagian besar melakukan perubahan ruang, yaitu merubah halaman belakang dan halaman depan menjadi ruang baru. Halaman belakang banyak dirubah menjadi dapur, ruang makan, ruang tidur dan kamar mandi/WC, sedangkan halaman depan sebagian besar dirubah menjadi teras, garasi dan carport. 
Pada ruang luar, penghuni juga melakukan penambahan material, penggantian warna, dan penambahan ragam hias. Penambahan material baru berupa besi dan keramik pada pagar rumah, sedangkan penggantian warna yang dipilih diantaranya warna-warna gelap seperti abu-abu dan hitam, serta warna-warna cerah seperti krem, merah, biru dan jingga. Ragam hias sebagian besar ditambahkan untuk memperindah tampilan pagar dan gerbang rumah dengan ornamen tertentu.

Sementara itu, pada fasad rumah, penghuni sebagian besar melakukan penambahan elemen dan penggantian warna. Penambahan elemen yang paling banyak dilakukan adalah penambahan keramik dinding dan atap pada fasad rumah, sedangkan penggantian warna pada fasad banyak menggunakan warna-warna cerah, seperti krem, merah, biru, hijau dan jingga. Dengan demikian dapat memberikan tampilan yang berbeda dengan tampilan eksistingnya.

Tipe-tipe pengembangan rumah subsidi yang teridentifikasi memverifikasi kembali aspekaspek pembentuk tipologi menurut Sulistijowati (1991), diantaranya aspek fungsi, geometrik, dan langgam. Aspek fungsi dapat diidentifikasi pada pengembangan pada ruang dalam dan ruang luar, aspek geometrik dapat diidentifikasi pada penggunaan material dan warna, sedangkan aspek langgam dapat diidentifikasi pada penggunaan ragam hias atau dekorasi pada fasad rumah.

\section{Pertimbangan-pertimbangan penghuni dalam mengembangkan rumahnya}

Tipe-tipe pengembangan rumah subsidi yang dilakukan oleh penghuni memperlihatkan pelbagai pertimbangan penghuni dalam mengembangkan rumahnya. Pertimbangan umum yang diakui oleh para penghuni adalah kemampuan ekonomi, karena pertimbangan ini mempengaruhi prioritas dan kompleksitas pengembangan rumah yang menyebabkan keragaman tipe pengembangan rumah subsidi oleh penghuni. Meskipun demikian, terdapat beberapa pertimbangan khusus penghuni yang mempengaruhi pengembangan rumahnya, yaitu:

1. Kebutuhan dasar penghuni

Kebutuhan dasar penghuni yang tidak diwadahi pada rumah subsidi salah satunya adalah kegiatan memasak. Hal ini dipengaruhi oleh keterbatasan tipe rumah subsidi yang tidak memungkinkan untuk dilengkapi dengan dapur yang memadai. Dengan demikian, dapur merupakan salah satu ruang yang wajib ditambahkan oleh penghuni ketika mengembangkan rumahnya karena terkait kebutuhan dasar penghuni.

2. Keamanan rumah

Rumah subsidi umumnya tidak dilengkapi dengan pagar rumah, sehingga rumah cenderung kurang aman karena tidak ada batas secara fisik di sekeliling rumah. Oleh karena itu, penambahan pagar dan gerbang menjadi salah satu pertimbangan penghuni dalam mengembangkan rumahnya. Pada umumnya, saat pagar dan gerbang rumah telah dibangun, penghuni melengkapinya dengan garasi atau carport untuk menjaga keamanan dan melindungi kendaraan dari pengaruh cuaca.

3. Tampilan rumah

Tampilan rumah merupakan salah satu pertimbangan penghuni dalam mengembangkan rumahnya, karena mengubah tampilan rumah dapat memperindah dan memberikan identitas pada rumah sehingga rumah lebih mudah dikenali dan berbeda dengan tampilan rumah lainnya. Mengubah tampilan rumah, diantaranya dilakukan dengan mengganti warna cat atau menambahkan ragam hias berupa ornamen dan dekorasi pada pagar atau fasad rumah.

4. Jumlah penghuni

Rumah subsidi sebagian besar dihuni oleh keluarga yang memiliki jumlah beragam. Hal ini menyebabkan rumah subsidi memiliki keterbatasan untuk mewadahi kebutuhan ruang seluruh penghuni, khususnya yang memiliki banyak anggota keluarga. Pada umumnya, rumah subsidi hanya dilengkapi dengan dua ruang tidur dan satu kamar mandi/WC, sehingga tidak mencukupi untuk satu keluarga yang berjumlah lebih dari empat orang. Hal ini menyebabkan 
penghuni akan melakukan pengembangan rumah dengan menambahkan ruang tidur dan kamar mandi/WC, sehingga dapat member kenyamanan untuk seluruh anggota keluarga.

5. Pekerjaan penghuni

Pertimbangan lainnya yang mempengaruhi pengembangan rumah subsidi adalah pekerjaan penghuni. Beberapa penghuni perumahan memiliki pekerjaan utama atau sampingan sebagai pedagang. Hal ini menyebabkan penghuni melakukan pengembangan rumahnya dengan menambahkan kios atau toko kelontong di depan rumahnya sebagai tempat berdagang.

6. Hobi penghuni

Penghuni umumnya memiliki hobi yang beragam, salah satunya adalah hobi berkebun. Hobi berkebun ini menjadi salah satu pertimbangan penghuni dalam mengembangkan rumahnya. Beberapa penghuni sengaja tidak menghabiskan seluruh lahan pekarangan rumahnya untuk dibangun, melainkan tetap dijadikan ruang terbuka untuk menyalurkan hobi berkebun di rumah. Hal ini juga dapat memberikan dampak positif untuk menambah keindahan rumah, menjaga ketersediaan ruang terbuka hijau dan resapan air hujan.

Pertimbangan-pertimbangan dalam mengembangkan rumah yang diperoleh dari hasil analisis tipe-tipe pengembangan rumah subsidi, menunjukan bahwa analisis tipologi suatu objek (dalam hal ini rumah subsidi), dapat digunakan untuk menggali ide atau gagasan yang mendasari terbentuknya sebuah objek yang beragam. Hal ini sesuai dengan pernyataan Moneo (1978), bahwa dengan menganalisis tipologi dapat diketahui ide atau gagasan yang mendasari keberadaan sebuah objek. Rumah-rumah subsidi yang memiliki beragam bentuk pengembangan dan dihuni oleh penghuni dengan latar belakang yang beragam, dapat disederhanakan menjadi beberapa tipe sehingga pertimbangan-pertimbangan yang melatarbelakangi keragaman pengembangan rumah subsidi tersebut dapat diidentifikasi secara lebih komprehensif.

\section{Kesimpulan}

Rumah subsidi merupakan program nasional yang dicanangkan pemerintah untuk menyediakan rumah tinggal layak huni bagi masyarakat ekonomi menengah ke bawah. Rumah subsidi yang berkonsep rumah tumbuh hanya dapat memenuhi kebutuhan dasar penghuni, sehingga memberi peluang bagi penghuni untuk mengembangkan rumahnya. Kebutuhan dan kemampuan masyarakat dalam mengembangkan rumahnya, membuat pengembangan rumah subsidi menjadi sangat beragam. Keragaman tersebut salah satunya dapat diidentifikasi di Kota Kupang, Nusa Tenggara Timur. Berdasarkan hasil penelitian, diperoleh tiga tipe pengembangan rumah subsidi oleh penghuni di Kota Kupang, NTT, yaitu:

1. Tipe 1 yaitu pengembangan rumah subsidi dengan penambahan ruang dan penggantian warna pada ruang dalam; ditambah perubahan ruang, penambahan material, penggantian warna dan penambahan ragam hias pada ruang luar; serta penambahan elemen dan penggantian warna pada fasad rumah.

2. Tipe 2 yaitu pengembangan rumah subsidi dengan penambahan ruang pada ruang dalam; ditambah perubahan ruang, penambahan material, penggantian warna dan penambahan ragam hias pada ruang luar; serta penambahan elemen dan penggantian warna pada fasad rumah.

3. Tipe 3 yaitu pengembangan rumah subsidi dengan penambahan ruang pada ruang dalam; ditambah perubahan ruang dan penggantian warna pada ruang luar; serta penambahan elemen dan penggantian warna pada fasad rumah.

Ketiga tipe pengembangan rumah subsidi tersebut menunjukan pelbagai pertimbangan penghuni dalam mengembangkan rumahnya. Kemampuan ekonomi merupakan pertimbangan umum yang mempengaruhi prioritas dan kompleksitas pengembangan, sehingga menyebabkan keragaman tipe pengembangan rumah subsidi oleh penghuninya. Sementara itu, pertimbangan khususnya antara lain: kebutuhan dasar penghuni, keamanan rumah, tampilan rumah, jumlah penghuni, pekerjaan dan hobi penghuni. Dengan melakukan pengembangan tersebut, penghuni dapat beraktivitas lebih 
nyaman dan optimal di rumah tinggalnya. Dengan demikian, hasil penelitian ini secara teoretis dapat memverifikasi kembali teori tipologi yang dikemukakan oleh Moneo (1978) pada objek dan waktu yang berbeda. Sementara itu, secara pragmatis dapat dijadikan masukan untuk mengembangkan perumahan dan rumah subsidi yang lebih optimal dan memadai di masa mendatang.

\section{Ucapan Terima Kasih}

Penelitian ini dapat terlaksana dengan baik berkat kontribusi dan dukungan dari pelbagai pihak.

Oleh karena itu, diucapkan terima kasih dan apresiasi kepada beberapa pihak, yaitu:

1. Pimpinan Universitas Nusa Cendana dan Pimpinan Fakultas Sains dan Teknik, Undana atas kesempatan yang diberikan untuk memperoleh pendanaan untuk melaksanakan penelitian ini.

2. Pengembang PT. Charson Timorland, PT. Putra Tunggal Mentari dan PT. Pembangunan Sehat Sejahtera atas izin dan dukungan selama melakukan penelitian di masing-masing perumahan.

3. Penghuni Perumahan Gemstone Regency, Perumahan Bello Royal Residence dan Perumahan Pondok Indah Matani atas informasi dan dukungan yang telah diberikan selama penelitian.

\section{Daftar Acuan}

Adlina, Z. (2019). Analisis Migrasi Penduduk Melalui Program Rumah Subsidi di Daerah Pinggiran Kota Medan. Jurnal Mukadimah, 3 (2): 49-54.

Asmarani, I. K., Antariksa, \& Ridjal, A. M. (2016). Tipologi Elemen Arsitektur Rumah Bangsal di Desa Larangan Luar Pamekasan Madura. Jurnal Tesa Arsitektur, 14 (1): 10-22.

Ayu, I. dan Elena, M. (2019, March 10). Kenapa Bank Lebih Memilih FLPP Dibanding KPR Nonsubsidi?. Retrieved from https://bisnis.com/ finansial $/ \mathrm{read} / 20191023 / 90 / 1162134 / \mathrm{kenapa}-$ bank-lebih-memilih-flpp-dibanding-kprnonsubsidi.

BPS. (2015). Kota Kupang Dalam Angka Tahun 2015. Kupang: Badan Pusat Statistik.

Faisal, G., Suwarno, N., \& Wihardyanto, D. (2012). Tipologi Ventilasi Bangunan Vernakular di Indonesia. Jurnal Arsitektur Universitas Bandar Lampung, 1 (3): 27-35.

Hardy, I G. N. W, Maromon, R. Y. Y., \& Amabi, D. A. (2020). Kajian Proses Pengembangan Rumah Subsidi Secara Mandiri di Kota Kupang, Nusa Tenggara Timur. Jurnal Gewang Universitas Nusa Cendana, 2 (2): 57-62.

Hartanu, D. A., \& Firdausy, C. M. (2018). Analisis Kelayakan Investasi Pengembangan Perumahan Subsidi di Kabupaten Tangerang. Jurnal Manajemen Bisnis dan Kewirausahaan, 2 (1): 36-45.

Huwaida, N. M., \& Harsritanto, B. I. R. (2019). Adaptasi Perumahan Pasca Bencana Longsor (Studi Kasus: Perumahan UNDIP Dewi Sartika, Semarang). Jurnal Arcade, 3 (3): 231-236.

Kamim, A. B. M., Amal, I., \& Khandiq, M. R. (2019). Problematika Perumahan Perkotaan di Kota Yogyakarta. Jurnal Sosiologi USK, 13 (1): 3454.

Kementerian PUPR. (2020, August 19). Pusat Pengelolaan Dana Pembiayaan Perumahan
$(P P D P P)$. Retrieved from https://sikumbang ppdpp.id

Mangeswuri, D. R. (2016). Kebijakan Pembiayaan Perumahan Melalui Fasilitas Likuiditas Pembiayaan Perumahan (FLPP). Jurnal Ekonomi \& Kebijakan Publik, 7 (1): 83-95.

Mithen. (2015). Tipologi Arsitektur Tradisional Mamasa, Sulawesi Barat. Jurnal Langkau Betang, 2 (1): 1-9.

Moneo, R. (1978). On Typology. Oppositions: A Journal for Ideas and Criticism in Architecture Vol. 13. The MIT Press.

Musyaqqat, S. R. (2018). Permukiman Selatan Kota Makassar: Perumahan BTN Minasa UPA 19802015. Jurnal Pangadereng, 4 (1): 137-153.

Prabowo, A. T., \& Roychansyah, S. (2017). Tipologi Rumah Tinggal Dengan Harga Rp. 100-200 Juta di Yogyakarta. Temu Ilmiah IPLBI, 6: 1-6.

Rachmawati, Y. (2019, March 9). NTT Minta Tambahan Kuota 1500 Unit Rumah Subsidi. Retrieved from https://kupang.tribunnews.com/ 2019/09/30/ntt-minta-tambahan-kuota-1500unit-rumah-subsidi

Rahman, N. V., Pane, I. F., \& Abdillah, W. (2018). Tipologi Bangunan Pada Kawasan Simarjarunjung (Menemukenali Perwajahan Bangunan Dengan Analisis Genius Loci). Temu Ilmiah IPLBI, 7: 71-78.

DOI: https://doi.org/10.32315/ti.7.h071

Ramli, S. (2018). Tipologi dan Morfologi Fasade Rumah Tradisional Kampung Ciptagelar. Jurnal Local Wisdom. Vol. 10 (2): 75-90.

Santoso, D.K., Antariksa, \& Utami, S. (2019). Tipologi Rumah-Ladang di Desa Enclave Taman Nasional Bromo Tengger Semeru, Ngadas, Kabupaten Malang. Jurnal Arsitektura, 17 (2): 271-282.

DOI: https://doi.org/10.20961/arst.v17i2.33140 
Schulz, C. N. (1985). The Concept of Dwelling on The Way to Figurative Architecture. Rizzoli.

Siswanti, D. D. (2013). Pengendalian Kepemilikan RSH Subsidi di Kelurahan Meteseh Kota Semarang. Jurnal Pembangunan Wilayah dan Kota (JPWK), 9 (2): 194-204.

Sulistijowati. (1991). Tipologi Arsitektur Pada Rumah Kolonial Surabaya (Studi Kasus: Perumahan Plampitan dan sekitarnya). Surabaya: Fakultas Teknik dan Perencanaan ITS.

Supeno, \& Ansori, M. (2019). Pengembangan Perumahan Berbasis Syariah dan Permasalahannya di Propinsi Jambi. Jurnal Ilmiah Universitas Batanghari Jambi (JIUBJ), 19 (3): 509-515. DOI: https://doi.org/10.33087/jiubj.v19i3.736
Wicaksono, D., Antariksa, \& Subekti, H. (2008). Perkembangan Permukiman dan Tipologi RumahTinggal Pada Perumahan Karyawan Pabrik Gula Pesantren Baru-Kediri. Arsitektur e-journal, 1 (1): 49-63.

Widodo, W., \& Sunarti, S. (2019). Pola Perkembangan Perumahan di Kota Surakarta. Jurnal Pembangunan Wilayah dan Kota (JPWK), 15 (4): 288300.

DOI: https://doi.org/10.14710/pwk.v15i4.21984

Yuliastuti, N., \& Sukmawati, A. M. (2016). Transformasi Perumahan Sosial dan Keberlanjutan Perumahan di Perumnas Sendangmulyo. Jurnal Pengembangan Kota, 4 (1): 87-94. 